\title{
RESEARCH
}

Open Access

\section{Cross-sectional study of medical advertisements in a national general medical journal: evidence, cost, and safe use of advertised versus comparative drugs}

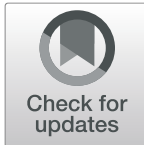

Kim Boesen ${ }^{1,2^{*}}$ (D) Anders Lykkemark Simonsen ${ }^{1}$, Karsten Juhl Jørgensen ${ }^{1,3,4}$ and Peter C. Gøtzsche ${ }^{5}$

\begin{abstract}
Background: Healthcare professionals are exposed to advertisements for prescription drugs in medical journals. Such advertisements may increase prescriptions of new drugs at the expense of older treatments even when they have no added benefits, are more harmful, and are more expensive. The publication of medical advertisements therefore raises ethical questions related to editorial integrity.

Methods: We conducted a descriptive cross-sectional study of all medical advertisements published in the Journal of the Danish Medical Association in 2015. Drugs advertised 6 times or more were compared with older comparators: (1) comparative evidence of added benefit; (2) Defined Daily Dose cost; (3) regulatory safety announcements; and (4) completed and ongoing post-marketing studies 3 years after advertising.

Results: We found 158 medical advertisements for 35 prescription drugs published in 24 issues during 2015, with a median of 7 advertisements per issue (range 0 to 11). Four drug groups and 5 single drugs were advertised 6 times or more, for a total of 10 indications, and we made 14 comparisons with older treatments. We found: (1) 'no added benefit' in 4 (29\%) of 14 comparisons, 'uncertain benefits' in 7 (50\%), and 'no evidence' in 3 (21\%) comparisons. In no comparison did we find evidence of 'substantial added benefit' for the new drug; (2) advertised drugs were 2 to 196 times (median 6) more expensive per Defined Daily Dose; (3) 11 safety announcements for five advertised drugs were issued compared to one announcement for one comparator drug; (4) 20 post-marketing studies (7 completed, 13 ongoing) were requested for the advertised drugs versus 10 studies (4 completed, 6 ongoing) for the comparator drugs, and 7 studies (2 completed, 5 ongoing) assessed both an advertised and a comparator drug at 3 year follow-up.

Conclusions and relevance: In this cross-sectional study of medical advertisements published in the Journal of the Danish Medical Association during 2015, the most advertised drugs did not have documented substantial added benefits over older treatments, whereas they were substantially more expensive. From January 2021, the Journal of the Danish Medical Association no longer publishes medical advertisements.
\end{abstract}

\footnotetext{
* Correspondence: kim.boesen@charite.de

${ }^{1}$ Nordic Cochrane Centre, Rigshospitalet Dept. 7811, 2100 Copenhagen,

Denmark

${ }^{2}$ Current address: Meta Research Innovation Center Berlin (METRIC-B), Berlin

Institute of Health, Charité Universitätsmedizin, QUEST Center for

Transforming Biomedical Research, Berlin, Germany

Full list of author information is available at the end of the article
}

(c) The Author(s). 2021, corrected publication 2021. Open Access This article is licensed under a Creative Commons Attribution 4.0 International License, which permits use, sharing, adaptation, distribution and reproduction in any medium or format, as long as you give appropriate credit to the original author(s) and the source, provide a link to the Creative Commons licence, and indicate if changes were made. The images or other third party material in this article are included in the article's Creative Commons licence, unless indicated otherwise in a credit line to the material. If material is not included in the article's Creative Commons licence and your intended use is not permitted by statutory regulation or exceeds the permitted use, you will need to obtain permission directly from the copyright holder. To view a copy of this licence, visit http://creativecommons.org/ licenses/by/4.0/. The Creative Commons Public Domain Dedication waiver (http://creativecommons.org/publicdomain/zero/1. 0/) applies to the data made available in this article, unless otherwise stated in a credit line to the data. 


\section{Introduction}

The pharmaceutical industry promotes prescription drugs in many ways, e.g. through sales visits to medical personnel, by arranging conferences with key opinion leaders, distributing reprints of studies published in prestigious medical journals, and through print advertisements [1]. Medical advertisements directed towards patients, often called" direct to consumer" advertisements, are allowed only in a few countries, including the United States and New Zealand. Opponents argue that these advertisements medicalise normal experiences and lead to unnecessary drug use [2]. Advocates argue that such advertisements increase patients' autonomy and raise awareness about new treatments and diseases that would otherwise remain underdiagnosed and undertreated [3].

To our knowledge, medical advertisements for health care professionals, i.e. marketing content about new prescription drugs sponsored by pharmaceutical companies, are allowed in most countries and published in most medical journals. Researchers have recommended medical journals to abandon such advertisements arguing that they make medical doctors prescribe new drugs at the expense of older, cheaper, and often equivalent or better alternatives [4]. PLOS Medicine is likely one of the few medical journals that has chosen to not bring medical advertisements. At the journal's inauguration, the editors stated they did not want to be part of a "cycle of dependency" with the pharmaceutical industry [5]. The International Committee of Medical Journal Editors (ICMJE) [6] and the World Association of Medical Editors (WAME) [7] recommend against medical advertisements to be juxtaposed to related scientific content. A case-control study of four international and three Russian medical journals (total of 214 issues) found 90 instances of advertisements published in an issue with closely related scientific content [8].

Medical advertisements may refer to data that do not substantiate claims or to data that is inaccessible [9-14], and they may present relative rather than absolute treatment effects, which could lead to exaggerated perceptions of treatment effects [15]. One third of antidepressant advertisements published in the Journal of the Swedish Medical Association between 1994 to 2003 violated the industry's own code of conduct [16], and $82 \%$ of medical advertisements published in a sample of American medical journals in 2008 did not comply fully with the US Food and Drug Administration (FDA) advertising guideline [17]. A systematic review of the quality of medical advertisements reported that only $8 \%$ of the advertisements' statements cited systematic reviews and $30 \%$ randomised trials [18]. Another systematic review found that exposure to pharmaceutical promotion was associated with increased prescription rates and costs, and lower quality of prescriptions, whereas there was no evidence of improved prescription quality, defined, for example, as adherence to prescription guidelines and appropriateness of prescriptions [19].

In this study we wanted to investigate which drugs were advertised in the Journal of the Danish Medical Association [20]. Additionally, for the most commonly advertised drugs, we wanted to assess the evidence for added benefit, cost, safety announcements, and drug regulator required post-marketing studies comparing with older prescription drugs for the same indication.

\section{Methods}

We followed the Strengthening the Reporting of Observational Studies in Epidemiology (STROBE) guideline [21] for reporting our results.

\section{The medical journal}

The Journal of the Danish Medical Association [20] is a general medical journal and a member of the International Committee of Medical Journal Editors (ICMJE). The journal is published biweekly in Danish and circulated in print to all members of the Danish Medical Association, which has approximately 30,000 medical doctors as members.

\section{Sample of advertisements}

Two observers (KB and ALS) independently assessed all issues of the Journal of the Danish Medical Association published in 2015 (excluding special issues). A third author (KJ) arbitrated in case of disagreements. We extracted information from all medical advertisements published during 2015. We did not include advertisements for over-the-counter drugs, dietary supplements, or medical devices. We extracted the following information: trade name, generic name, drug class, indication, and sponsor. We categorised each advertisement according to the most relevant medical specialty. We looked up each advertisement's indication (e.g. hypercholesterolaemia) in a Danish medical reference [22] and adopted its specialty categorisation (e.g. endocrinology).

In the European Union, medical advertisements must be juxtaposed by the product information, the Summary of Product Characteristics (SmPC) [23]. Some SmPCs may resemble actual advertisements by including logos, illustrations, tables, or descriptive text in addition to the mandated text. We therefore included those SmPCs that contained more than the legally required [23] information as advertisements. The results were summarised in Excel and are presented as summary statistics, i.e. percentages and medians.

\section{Advertisements coinciding with scientific content}

We assessed whether advertisements for speciality drugs, i.e. drugs that are used and prescribed by specialists, 
appeared in issues with related scientific articles, e.g. narrative reviews related to the specialist drug.

\section{Comparison of most commonly advertised drugs versus older comparators}

One author (KB) assessed the most advertised drugs with 6 or more advertisements. We grouped advertised drugs if they belonged to the same drug class, e.g. combination beta $_{2}$-agonist and steroid formulations, or if they were advertised for the same specific indication, e.g. treatment of atrial fibrillation. We compared these most commonly advertised drugs or drug groups, with clinically relevant comparators. We defined the relevant comparators as single components of combination formulations, regular pill formulations of modified release formulations, or first-choice treatments for the advertised condition. See also the Supplementary file, eMethods. We made four analyses for these advertised drugs and their relevant comparators:

\section{Evidence for added benefits}

We searched for direct comparative evidence in Cochrane reviews, the Institute for Quality and Efficiency in Healthcare's (IQWiG) assessment reports, FDA Medical Office Reviews and the European Medicines Agency's (EMA) Public Assessment Reports, in that order. We categorised the evidence for added benefit of the advertised drug (for the advertised indication) relative to the comparator as 'substantial added benefits', 'uncertain benefits', 'no added benefits', or 'no evidence'. See also Supplementary file, eMethods for details.

\section{Defined Daily Dose cost analysis}

We compared the advertised drugs' Defined Daily Dose to those of the relevant comparators. We obtained prices from the Danish Medicines Agency [24].

\section{EMA and FDA safety announcements}

We searched the FDA Drug Safety Communication [25] archive and EMA's medicines database [26] for safety announcements pertaining to the advertised drugs and their relevant comparators. We searched for announcements published within a three-year follow-up period after advertising between 2015 and 2018 .

\section{Post-marketing studies}

We searched for drug regulator required postmarketing studies registered in the FDA Postmarket Requirements and Commitments database [27] and the European Union electronic Register of Post-Authorisation
Studies [28]. We categorised the studies according to their status at 3 years of follow-up (December 2018) from advertising as: 'completed' (results reported before December 2018), or 'ongoing' (results reported, or planned to be reported, after December 2018). See the Supplementary file, eMethods for details.

\section{Results}

\section{Summary results}

During 2015, there were 158 medical advertisements for 35 different prescription drugs, published in 24 issues with a median of 7 per issue (range 0 to 11). Of the 158 advertisements, 35 (22\%) were Summary of Product Characteristics that contained more than the legally required text. In two issues (no. 19 and no. 23), seven of the first nine pages were medical advertisements or SmPCs. In the two issues published during Danish summer holiday (July), there were no advertisements. See the full list of advertisements in Supplementary file, eTable 1. Drugs often prescribed in general practice were the most frequently advertised. Advertisements for pulmonology appeared most frequently $(n=57,36 \%)$, followed by psychiatry $(n=32,20 \%)$, analgesics $(n=17$, $11 \%)$, endocrinology $(n=15,8 \%)$, and urology $(n=8$, 5\%), see Supplementary file, eTable 2.

\section{Advertisements coinciding with scientific content}

We found seven cases of advertisements for six specialist drugs appearing in issues with related scientific content, Supplementary file eTable 3. In three cases, the advertised drugs were directly mentioned in narrative reviews appearing in the same issue. In four cases, the advertisements appeared in issues with closely related scientific content, but the drugs were not directly mentioned.

\section{Comparison of most commonly advertised drugs versus older comparators}

Four drug groups, combined beta ${ }_{2}$-agonist + steroid inhalations (three drugs), combined beta ${ }_{2}$-agonist + anticholinergic agent inhalations (three drugs), ADHD medications (two drugs), and new oral anticoagulants (two drugs) and five single drugs, modified-released paracetamol, vortioxetine, aripiprazole intramuscular depot, pneumococcal vaccine, and canagliflozin, were advertised $\geq 6$ times during 2015, Table 1 . The sample accounted for 118 (75\%) of the 158 advertisements. We compared these frequently advertised drugs with older comparators in four analyses:

\section{Evidence for added benefits}

The most advertised drugs (four drug groups, five single drugs) were advertised for 10 different indications and we made 14 comparisons with older comparators, 
Table 1 Basic information on the most advertised drugs and drug groups

\begin{tabular}{|c|c|c|c|}
\hline Advertised drug (n advertisements) & Brand name & EMA authorisation ${ }^{a}$ & Marketing holder ${ }^{\mathbf{b}}$ \\
\hline \multicolumn{4}{|l|}{ Drug groups } \\
\hline \multicolumn{4}{|l|}{ Beta2-agonist + steroid inhalations (28) } \\
\hline Vilanterol + fluticasone furoate (11) & Relvar Ellipta & Nov 2013 & GlaxoSmithKline \\
\hline Formoterol + budesonide (9) & DuoResp Spiromax & April 2014 & Teva Pharma \\
\hline Formoterol + fluticasone propionate (8) & Flutiform & June 2012 & Norpharma \\
\hline \multicolumn{4}{|l|}{ Beta2-agonist + anticholinergic agents (26) } \\
\hline Olodaterol + tiotropium (18) & Spiolto Respimat & $N / A^{c}$ & Boehringer Ingelheim \\
\hline Vilanterol + umeclidinium (5) & Anoro Ellipta & May 2014 & GlaxoSmithKline \\
\hline Formoterol + aclidinium bromide (3) & Duaklir Genuair & Nov 2014 & Astra Zeneca \\
\hline \multicolumn{4}{|l|}{ ADHD medications (16) } \\
\hline Lisdexamfetamine (12) & Aduvanz & $N / A^{c}$ & Shire Pharmaceuticals \\
\hline Atomoxetine (4) & Strattera & $N / A^{c}$ & Eli Lilly \\
\hline \multicolumn{4}{|l|}{ New oral anticoagulants (6) } \\
\hline Rivaroxaban (4) & Xarelto & June 2013 & Bayer \\
\hline Dabigatran (2) & Pradaxa & Aug 2011 & Boehringer Ingelheim \\
\hline \multicolumn{4}{|l|}{ Single drugs } \\
\hline Paracetamol modified-release (15) & Panodil 665 & $N / A^{c}$ & GlaxoSmithKline \\
\hline Vortioxetine (8) & Brintellix & Dec 2013 & Lundbeck \\
\hline Aripiprazole intramuscular depot (7) & Abilify Maintena & Nov 2013 & Otsuka/Lundbeck \\
\hline Pneumococcal vaccine (6) & Prevenar 13 & Jan 2010 & Pfizer \\
\hline Canagliflozin (6) & Invokana & Nov 2013 & Janssen-Cilag \\
\hline
\end{tabular}

${ }^{a}$ We used the EMA year of approval as a proxy for regulatory approval in Denmark. ${ }^{\text {b}}$ The marketing holder is the pharmaceutical company that also sponsors the advertisements. 'We where not able to find relevant information on the EMA website. These drugs were likely approved through decentralised procedures, which means that a European national drug regulator authorised the drug and not EMA

Table 2. We used Cochrane systematic reviews (six comparisons), IQWiG reports (two), FDA reports (two), EMA report (one), and a single trial for one comparison. For two comparisons we found no evidence source. We included additional evidence outside of our stipulated search strategy for four comparisons (beta ${ }_{2}$-agonist + steroid combination for asthma, atomoxetine for adult ADHD, vortioxetine for depression, and pneumococcal vaccines for invasive pneumonia), Table 2 .

The advertised drugs had evidence of 'substantial added benefits' compared to older relevant comparators in none $(0 \%)$ of the comparisons, there were 'uncertain benefits' in seven (50\%) comparisons, and evidence of 'no added benefits' of the advertised drugs in four (29\%) comparisons. For three (21\%) comparisons there was 'no evidence', Table 2. See the Supplementary file, 'Evidence for the advertised drugs' and eTable 4, for details on each comparison.

\section{Defined Daily Dose cost analysis}

The advertised drugs were two to 196 times (median of 6) more expensive measured as the Defined Daily Dose than the older comparators, Table 3. For unknown reasons, the Danish Medicines Agency did not report the Defined Daily Dose for inhalation combination drugs, and we could not make a price comparison for the pneumococcal vaccine against placebo.

\section{EMA and FDA announcements}

Between 2015 and 2018, EMA and FDA made 11 announcements related to five of the advertised drugs, and one announcement also pertained to a relevant comparator (FDA's warning on aripiprazole), Table 4. The FDA issued nine Drug Safety Communications ( canagliflozin $=7 ;$ aripiprazole $=1 ;$ combined beta $_{2}$ agonist and steroid inhalation formulation =1) and EMA issued two Referrals (inhaled corticosteroids for chronic obstructive pulmonary disorder (COPD) and modified-release paracetamol). Most warnings related to new harms, whereas one safety announcement informed that combination beta $_{2}$-agonist + steroid formulations did not increase the risk of serious asthma related outcomes. EMA's Referral on modified-release paracetamol announced the drug's withdrawal from the European market due to difficulties in managing drug overdoses. 
Table 2 Comparative evidence for the most advertised drugs and drug groups

\begin{tabular}{|c|c|c|c|c|}
\hline Advertised drug & Indication & Comparison & Reviewed evidence & $\begin{array}{l}\text { Evidence } \\
\text { categorisation }\end{array}$ \\
\hline \multicolumn{5}{|l|}{ Drug groups } \\
\hline $\begin{array}{l}\text { 1. Beta2-agonist }+ \text { steroid } \\
\text { inhalations }\end{array}$ & 1. Asthma & 1. Steroid inhalation only & $\begin{array}{l}\text { Systematic review [29] + FDA } \\
\text { analysis [30] }\end{array}$ & $\begin{array}{l}\text { Uncertain } \\
\text { benefits }\end{array}$ \\
\hline- & 2. COPD & $\begin{array}{l}\text { 2. Beta-agnoist inhalation } \\
\text { only }\end{array}$ & Systematic review [31] & $\begin{array}{l}\text { Uncertain } \\
\text { benefits }\end{array}$ \\
\hline $\begin{array}{l}\text { 2. Beta2-agonist }+ \text { anti- } \\
\text { cholinergic agents }\end{array}$ & 2. COPD & 3. Beta 2 -agonist only & Systematic review [32] & $\begin{array}{l}\text { Uncertain } \\
\text { benefits }\end{array}$ \\
\hline- & 2. COPD & $\begin{array}{l}\text { 4. Anticholinergic agent } \\
\text { only }\end{array}$ & Systematic review [32] & $\begin{array}{l}\text { Uncertain } \\
\text { benefits }\end{array}$ \\
\hline \multicolumn{5}{|l|}{ 3. ADHD medications } \\
\hline Lisdexamfetamine & 3. ADHD & 5. Methylphenidate & No evidence source & No evidence \\
\hline Atomoxetine & 3. ADHD & 6. Methylphenidate & One clinical trial [33] & $\begin{array}{l}\text { No added } \\
\text { benefits }\end{array}$ \\
\hline \multicolumn{5}{|l|}{ 4. New oral anticoagulations } \\
\hline Rivaroxaban & 4. Atrial fibrillation & 7. Warfarin & FDA report [34] & $\begin{array}{l}\text { No added } \\
\text { benefits }\end{array}$ \\
\hline Dabigatran & 4. Atrial fibrillation & 8. Warfarin & FDA report [35] & $\begin{array}{l}\text { No added } \\
\text { benefits }\end{array}$ \\
\hline \multicolumn{5}{|l|}{ Single drugs } \\
\hline $\begin{array}{l}\text { 5. Paracetamol modified- } \\
\text { release }\end{array}$ & 5. Pain & 9. Regular paracetamol & No evidence source & No evidence \\
\hline 6. Vortioxetine & 6. Depression & 10. Duloxetine & Systematic review $[36]^{a}$ & $\begin{array}{l}\text { No added } \\
\text { benefits }\end{array}$ \\
\hline $\begin{array}{l}\text { 7. Aripiprazole intramuscular } \\
\text { depot }\end{array}$ & 7. Schizophrenia & 11. Aripiprazole oral tablet & EMA report [37] & $\begin{array}{l}\text { Uncertain } \\
\text { benefits }\end{array}$ \\
\hline 8. Pneumococcal vaccine & 8. Pneumococcal pneumonia & 12. Placebo & $\begin{array}{l}\text { Systematic review [38] + } \\
\text { clinical trial [39] }^{\text {a }}\end{array}$ & $\begin{array}{l}\text { Uncertain } \\
\text { benefits }\end{array}$ \\
\hline 9. Canagliflozin & $\begin{array}{l}\text { 9. Diabetes mellitus type } 2 \text { (single } \\
\text { therapy) }\end{array}$ & 13. Glimeride & IQWiG report [40] & No evidence \\
\hline- & $\begin{array}{l}\text { 10. Diabetes mellitus type } 2 \text { (add- } \\
\text { on to metformin) }\end{array}$ & $\begin{array}{l}\text { 14. Glimerpiride add-on to } \\
\text { metformin }\end{array}$ & IQWiG report [40] & $\begin{array}{l}\text { Uncertain } \\
\text { evidence }\end{array}$ \\
\hline
\end{tabular}

$A D H D$ attention deficit hyperactivity disorder; COPD chronic obstructive pulmonary disorder. ${ }^{\mathrm{a}}$ For four comparisons we included evidence identified outside our stipulated search strategy. We have detailed this in the Supplement, eTable 8

\section{Post-marketing studies}

We identified 37 drug regulator requested postmarketing studies, 33 in the EU database and four in the FDA database. By December 2018, 12 studies were completed and 25 were ongoing, Table 5. Twenty (54\%) post-marketing studies (7 completed, 13 ongoing) related to the advertised drugs (beta ${ }_{2}$-agonist + anticholinergic combinations $=4 ; \quad$ canagliflozin $=5 ; \quad$ combined beta $_{2}$-agonist + steroid $=3$; rivaroxaban $=3$; vortioxetine $=2$; aripiprazole, dabigatran, and lisdexamfetamin one each), Supplementary file eTable 5 . Ten (27\%) studies (4 completed, 6 ongoing) related to four comparator drugs (duloxetine $=5$; methylphenidate $=2$; umeclidinium $=2$, metformin $=1$ ), Supplementary file eTable 6 . Finally, Seven (19\%) studies (2 completed, 5 ongoing) assessed an advertised and a comparator drug (beta ${ }_{2}$ agonist and anticholinergic combinations versus single components $=4$; dabigatran, rivaroxaban and warfarin $=$ 2; paracetamol all formulations $=1$ ), Supplementary file eTable 7.

The postmarketing studies assessed specific harms (24, $65 \%)$, benefits and harms (11,22\%), and prescription patterns (2, 5\%), e.g. off-label use. All studies had an observational design, e.g. pharmacovigilance and cohort studies, except one randomised clinical trial for the antidepressant vortioxetine.

\section{Discussion}

\section{Key results}

To our knowledge, this is the first cross-sectional study to assess all medical advertisements published in a general medical journal throughout a calendar year. We judged that none of the most frequently advertised drugs were supported by evidence of 'substantial added benefits' compared to relevant comparators. This 
Table 3 Defined Daily Dose cost analysis

\begin{tabular}{|c|c|c|c|c|}
\hline Advertised drug (defined daily dose) & $\begin{array}{l}\text { Cost per Defined } \\
\text { Daily Dose (DKK) }\end{array}$ & Older comparator & $\begin{array}{l}\text { Cost per Defined } \\
\text { Daily Dose (DKK) }\end{array}$ & Price ratio \\
\hline Aripiprazole (400 mg as intramuscular injection) & 102,41 & Aripiprazole (15 mg as pill formulation) & 0,52 & 196 \\
\hline Canagliflozin (300 mg) & 10,41 & Glimepiride (2 mg) & 0,13 & 80 \\
\hline Rivaroxaban (20 mg) & 21,66 & Warfarin $(7,5 \mathrm{mg})$ & 3,49 & 6 \\
\hline Dabigatran (300 mg) & 22,22 & Warfarin $(7,5 \mathrm{mg})$ & 3,49 & 6 \\
\hline Atomoxetine $(80 \mathrm{mg})$ & 32,90 & Extended-release methylphenidate $(30 \mathrm{mg})^{\mathrm{a}}$ & 6,71 & 5 \\
\hline Vortioxetine (10 mg) & 7,65 & Duloxetine (60 mg) & 1,95 & 4 \\
\hline Lisdexamfetamine (30 mg) & 17,23 & Extended-release methylphenidate $(30 \mathrm{mg})^{\mathrm{a}}$ & 6,71 & 3 \\
\hline Paracetamol 665 mg (3990 mg) b & 3,83 & Paracetamol 500 mg (4000 mg) & 1,75 & 2 \\
\hline
\end{tabular}

DKK Danish Crowns (7,45 DKK approx. 1 Euro). Prices were obtained from the Danish Medicines Agency in March 2019. ${ }^{2}$ Doses are reported as defined daily doses, and may not correspond to the used doses in a clinical setting. ${ }^{\mathrm{b}}$ These are the 2017-prices, before the modified-release paracetamol was withdrawn from the EU market

corresponds with recent reports that the evidence for the majority of new cancer drugs [52] and newly authorised drugs in Germany demonstrate little or no added patient-relevant benefits over existing treatments [53]. Our analyses highlight, perhaps unsurprisingly, that advertised drugs were substantially more expensive than existing drugs on the market, which may be important in the light of the poor evidence for added value to the patients. Finally, we found that there were numerically more safety announcements issued regarding newly identified harms and more uncompleted post-marketing studies addressing potential harms related to the advertised drugs at three years of follow-up. This may indicate a larger uncertainty related to the clinical use of newer drugs compared to older comparators. In general, our study seems to add to the existing literature that medical advertisements directed towards healthcare professionals may not have beneficial effects but may have important negative effects.

\section{Interpretation}

We published an abridged version of this paper as an opinion piece in the Journal of the Danish Medical Association in 2018 in Danish [54] and encouraged the Danish Medical Association to ban medical advertisements.

Table 4 EMA and FDA safety announcements published after advertising (2015-2018)

\begin{tabular}{|c|c|c|c|c|}
\hline Drug & Clinical findings & Regulator & Regulatory action & Announcement \\
\hline Canagliflozin & Increased risk of ketoacidosis & FDA & $\begin{array}{l}\text { Undertaking further investigations (all } \\
\text { SGLT2-inhibitors) }\end{array}$ & May 2015 [41] \\
\hline Canagliflozin & $\begin{array}{l}\text { Increased risk of bone fractures and } \\
\text { decreased bone mineral density }\end{array}$ & FDA & $\begin{array}{l}\text { Warning added to the FDA prescriber } \\
\text { information }\end{array}$ & Sep 2015 [42] \\
\hline Canagliflozin & $\begin{array}{l}\text { Increased risk of ketoacidosis, urosepsis, } \\
\text { and pyelonephritis }\end{array}$ & $\mathrm{FDA}^{\mathrm{a}}$ & $\begin{array}{l}\text { Warning added to the FDA prescriber } \\
\text { information (all SGLT2-inhibitors) }\end{array}$ & Dec 2015 [43] \\
\hline Aripiprazole & $\begin{array}{l}\text { Impulse-control problems (gambling, } \\
\text { binge eat, shop, sex) }\end{array}$ & FDA & $\begin{array}{l}\text { Warning added to the FDA prescriber } \\
\text { information }^{\mathrm{a}}\end{array}$ & May 2016 [44] \\
\hline Canagliflozin & $\begin{array}{l}\text { Interim results: Increased risk of leg and } \\
\text { foot amputations }\end{array}$ & FDA & Undertaking further investigations & May 2016 [45] \\
\hline Canagliflozin & Risk of acute kidney injury & FDA & $\begin{array}{l}\text { Revised warning on the FDA prescriber } \\
\text { information }\end{array}$ & June 2016 [46] \\
\hline $\begin{array}{l}\text { Inhaled corticosteroids for } \\
\text { COPD }\end{array}$ & Increased risk of pneumonia & EMA & Updated product information & July 2016 [47] \\
\hline Canagliflozin & Increased risk of foot and leg amputation & $\mathrm{FDA}^{\mathrm{a}}$ & Addition of FDA boxed warning & May 2017 [48] \\
\hline $\begin{array}{l}\text { Combined beta }{ }_{2} \text {-agonist }+ \\
\text { steroid inhalation }\end{array}$ & $\begin{array}{l}\text { No increased risk of serious asthma-related } \\
\text { outcomes }\end{array}$ & FDA & Removal of FDA boxed warning & Dec 2017 [49] \\
\hline $\begin{array}{l}\text { Modified-release } \\
\text { paracetamol }\end{array}$ & Difficulties in managing overdoses & EMA & Withdrawal of product from EU market & Dec 2017 [50] \\
\hline Canagliflozin & $\begin{array}{l}\text { Increased risk of necrotising fasciitis of the } \\
\text { perineum }\end{array}$ & FDA & $\begin{array}{l}\text { Warning added to the FDA prescriber } \\
\text { information (all SGLT2-inhibitors) }\end{array}$ & Aug 2018 [51] \\
\hline
\end{tabular}

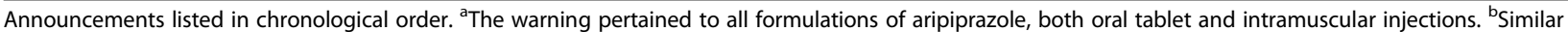
referral issued by EMA 
Table 5 Post-marketing studies ongoing at three year follow-up after advertising (Dec 2018)

\begin{tabular}{|c|c|c|c|}
\hline Drug & Study ID & Requested & Clinical question \\
\hline \multicolumn{4}{|l|}{ Advertised drugs } \\
\hline Aripiprazole IM & EUPAS21056 & EMA & Specific harms (extrapyramidal symptoms) \\
\hline Canagliflozin & EUPAS27670 & EMA & Specific harm (lower limb amputations) \\
\hline Canagliflozin & NDA 204042 commitment no. 1 & FDA & Specific harm (ketoacidosis) \\
\hline Canagliflozin & NDA 204042 commitment no. 3 & FDA & Specific harm (various conditions) \\
\hline Fluticasone propionate / formoterol & EUPAS3702 ${ }^{\mathrm{a}}$ & MHRA & Benefits and harms \\
\hline Lisdexamfetamin & EUPAS20546 & EMA & Specific harm (cardiovascular events) \\
\hline Rivaroxaban & $\begin{array}{l}\text { EUPAS11299, EUPAS9895, EUPAS11141, } \\
\text { and EUPAS11145 }\end{array}$ & EMA & $\begin{array}{l}\text { Specific harms (bleeding events and } \\
\text { liver disease) }\end{array}$ \\
\hline Tiotropium / olodaterol & EUPAS14273 & Japan & Long-term benefits and harms \\
\hline Tiotropium / olodaterol & EUPAS21574 & EMA & Specific harms (cardiovascular) \\
\hline Tiotropium / olodaterol & EUPAS14956 & South Korea & Benefits and harms \\
\hline Umeclidinium/ vilanterol & EUPAS9868 & Japan & Benefits and harms \\
\hline Umeclidinium/ vilanterol & EUPAS11397 & South Korea & Benefits and harms \\
\hline Vortioxetine & NDA 204447 commitment no. 6 & FDA & Benefits and harms \\
\hline Vortioxetine & EUPAS19199 & EMA & Clinical use and several specific harms \\
\hline \multicolumn{4}{|l|}{ Comparator drugs } \\
\hline Duloxetine & EUPAS20253 ${ }^{b}$ & United States & Specific harms (maternal and fetal harms) \\
\hline Duloxetine & NDA 21427 commitment no. 2 & FDA & Specific harms (maternal and fetal harms) \\
\hline Methylphenidate & EUPAS4551 ${ }^{\mathrm{C}}$ & EMA & Harms \\
\hline Methylphenidate & EUPAS3985 ${ }^{c}$ & EMA & Long-term harms \\
\hline Umeclidinium & EUPAS14947 & South Korea & Benefits and harms \\
\hline Umeclidinium & EUPAS10224 & Japan & Benefits and hams \\
\hline \multicolumn{4}{|l|}{ Advertised drugs and comparator drugs } \\
\hline Aclidinium and aclidinium/ formoterol & EUPAS6559 & EMA & Clinical use \\
\hline Aclidinium and aclidinium/ formoterol & EUPAS13616 & EMA & Specific harms (cardiovascular and mortality) \\
\hline Dabigatran and rivaroxaban, versus warfarin & EUPAS13017 & France & Benefits and harms \\
\hline Olodaterol and olodaterol/tiotropium & EUPAS21574 & EMA & Specific harms (cardiovascular events) \\
\hline Umeclidinium and umeclidinium/ vilanterol & EUPAS10316 & EMA & $\begin{array}{l}\text { Specific harms (cardiovascular and } \\
\text { cerebrovascular events) }\end{array}$ \\
\hline
\end{tabular}

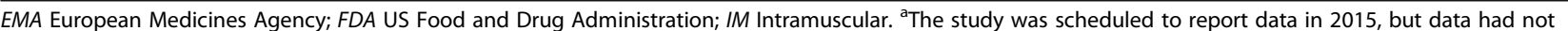
been submitted. ${ }^{\mathrm{b} T h i s ~ s t u d y}$ may likely be the same. ${ }^{\circ}$ The two methylphenidate studies were planned to finish in 2014 and 2015 , but they were listed as ongoing since data had not been reported on the website

On 19 June 2020, the Delegation of the Danish Medical Association voted to abolish medical advertisements [55] and, to our knowledge, this may be the first national medical association to make such a decision. We do not know if, and if so, to what degree, our work $[54,56]$ and advocacy for banning medical advertisements influenced this decision.

Nevertheless, an important question remains whether other medical associations, medical societies, and their respective medical journals could and should follow suit and abolish such advertisements. We are not aware of discussions regarding such a ban of advertisements for healthcare professionals in Europe. In contrast, on several occasions the introduction of 'direct to consumer' advertisements have been proposed to the European Commission [57, 58]. Similarly, we are not aware of discussions in the United States related to a ban of these advertisements directed at healthcare professionals, despite pharmaceutical companies spending more money on marketing directed at healthcare professionals than on 'direct to consumer' marketing. In 2016, a total of $\$ 20.3$ billion was spent on marketing directed at healthcare professionals in the US compared to $\$ 9.6$ billion on "direct to consumer" marketing [59]. Interestingly, it has long been debated in the US whether 'direct to consumer' advertisements should be banned [60] and in 2015, the American Medical Association advocated for such a ban stating these advertisements increase the use 
of more expensive and less effective treatments [61]. The same case could likely be made for advertisements directed at healthcare professionals.

Revenue from medical advertisements is intrinsic to the current biomedical publishing model, along with other revenues, such as sales of re-prints [62]. A crosssectional study of six medical societies in 1996 estimated that advertising revenue accounted for 2 to $31 \%$ of the associations' total revenue [63]. Major medical publishers report very large profit margins, e.g. Informa (who owns Taylor \& Francis) reported an operating profit of $£ 933$ million (32\%) of a total revenue of $£ 2,9$ billion in 2019 (p. 161) [64]. Elsevier reported an adjusted operating profit of $£ 982$ million (37\%) of a total revenue of $£ 2,6$ billion in 2019 [65]. Interestingly, only $2 \%$ of this revenue came from advertising whereas subscription fees was the major source of income (p. 16) [65]. An informed guess is therefore that abolishing of medical advertisements is economically feasible for major journals and publishers.

The impact on public health of advertisement to healthcare professionals may also not be trivial. The current 'opioid crisis' has been associated with marketing of OxyContin directed towards doctors falsely highlighting its low potential for addiction [66]. An American observational study [67] reported a positive association between opioid marketing directed at doctors, prescription rates, and overdose mortality, and registry studies $[68,69]$ have suggested that a major cause for the recent decrease in the US overall life expectancy is opioidrelated mortality. The American Centers for Disease Control and Prevention estimates that nearly 500.000 Americans died because of an opioid related overdose between 1999 and 2019 [70].

\section{Limitations}

Our study has several limitations, most importantly the lack of preregistration and specification of our methodology, including pre-defining how to select the comparator drugs. We only assessed advertisements during one year and in one medical journal, yielding a relatively small sample of issues and advertisements, which prevented us from making inferential statistics.

We grouped drugs if they belonged to the same drug class, and some comparisons might therefore have been affected. However, regardless of our preferred 'unit of analysis', drugs lumped into groups or individual assessments, our conclusions would likely be similar. For example, the most advertised drug, the combination drug tiotropium/olodaterol indicated for COPD, was included in the 'beta ${ }_{2}$-agonist and anti-cholinergic combination' group. According to an IQWiG report [71], this drug has "proof of lesser benefit" compared to a beta -agonist $^{-}$ or an anti-cholinergic agent alone. Individual drug assessments might even have led to more critical assessments.

While evidence categorisation always contains a degree of subjectivity, we believe that our methods and analyses are transparently reported and that other researchers would likely come to the same conclusions. Some might consider our inclusion of additional evidence outside our stipulated search strategy for some comparisons as unsystematic and potentially biased. It is important to note that the inclusion of this additional evidence did not change our evidence classifications. On the contrary, these efforts illustrate how difficult it may be to obtain the best and most complete available evidence. In fact, difficulties in identifying relevant direct comparisons might illustrate a general problem in the current regulatory drug approval system [53], rather than being a limitation to our project. We consider it an advantage that our evidence categorisation was based on systematic reviews and regulatory drug reports, which often include raw data from pivotal trials.

There might be other approaches to assessing the comparative safety of new versus older drugs than using safety announcements and post-marketing studies as the metric. The number of post-marketing studies does not necessarily indicate a greater uncertainty related to the use of new drugs compared to the older comparators, but rather that new drugs are subject to more scrutiny upon, and after, authorisation. Nevertheless, the higher number of unfinished post-marketing studies and safety announcements imply an uncertainty related to the prescription of these new drugs that did not apply to older comparators. Importantly, these uncertainties may not be conveyed to patients until many years after these drugs have been advertised heavily. Finally, we searched for post-marketing studies related to the single components of the combination inhalation formulations, but we did not search for all authorised single component beta $_{2}$-agonists, anticholinergic agents, and steroid drugs. However, it is unlikely this would have impacted our overall results.

\section{Generalisability}

We assessed a single medical journal during one calendar year and the results may therefore not be generalisable. However, the Journal of the Danish Medical Association is a national general medical journal circulated to all members of the Danish Medical Association across specialties and settings, which makes us believe that the assessed sample of advertised drugs was broad and may reflect well on content in other general medical journals. Our Defined Daily Dose cost analysis applies to Denmark and only at the time of analysis. Cost difference-ratios will be different in other countries and fluctuate over time [72]. 
We did not assess all advertised drugs, which were beyond the resources available for this research project. The assessed cohort of advertised drugs included commonly used drugs and we believe that our findings likely are transferable to other general medical journals.

\section{Conclusion}

In this cross-sectional study of medical advertisements published in a Danish general medical journal during 2015, we did not find evidence of substantial added benefits of the most advertised drugs over older comparators. The advertised drugs were substantially more expensive and likely related to more uncertain use measured on the number of EMA and FDA safety announcements and unfinished post-marketing studies at three years follow-up after the advertisement. The Journal of the Danish Medical Association stopped publishing medical advertisements from 2021.

\section{Supplementary Information}

The online version contains supplementary material available at https://doi. org/10.1186/s41073-021-00111-9.

Additional file 1.

\section{Acknowledgments}

Not applicable.

\section{Authors' contributions}

KB had full access to all the data in the study and takes responsibility for the integrity of the data and the analyses. $\mathrm{KB}$ is the guarantor of the study. Concept and design: KB, PCG. Data extraction: KB, ALS. Analysis of the data: All authors. First draft: KB. All authors read and approved the final manuscript.

\section{Funding}

No funding.

\section{Availability of data and materials}

The full list of advertisements is available in in the supplement. The issues of the Journal of the Danish Medical Association are available upon subscription from http://ugeskriftet.dk.

\section{Declarations}

Ethics approval and consent to participate

Not applicable.

\section{Consent for publication \\ Not applicable.}

\section{Competing interests}

None known.

\section{Author details}

${ }^{1}$ Nordic Cochrane Centre, Rigshospitalet Dept. 7811, 2100 Copenhagen, Denmark. ${ }^{2}$ Current address: Meta Research Innovation Center Berlin (METR IC-B), Berlin Institute of Health, Charité Universitätsmedizin, QUEST Center for Transforming Biomedical Research, Berlin, Germany. ${ }^{3}$ Centre for Evidence-Based Medicine (CEBMO) and Cochrane Denmark, Dept. Clinical Research, University of Southern Denmark, Odense, Denmark. ${ }^{4}$ Open Patient data Exploratory Network (OPEN), Odense University Hospital, Odense, Denmark. Institute for Scientific Freedom, 2970 Copenhagen, Denmark.
Received: 29 June 2020 Accepted: 11 April 2021

Published online: 10 May 2021

\section{References}

1. Dickersin K, Goodman S. The long and creative arm of the drug industry. Lancet. 2005;365(9460):656. https://doi.org/10.1016/S0140-6736(05)17943-4

2. Mintzes B. For and against: direct to consumer advertising is medicalising normal human experience: for. BMJ. 2002;324(7342):908-9. https://doi.org/1 0.1136/bmj.324.7342.908.

3. Bonoccorso SN, Sturchio JL. Direct to consumer advertising is medicalising normal human experience. Against BMJ. 2002;324:910-1.

4. Fugh-Berman A, Alladin K, Chow J. Advertising in medical journals: should current practices change? PLoS Med. 2006;3(6):e130. https://doi.org/10.1371/ journal.pmed.0030130.

5. The PLOS Medicine editors. Prescription for a healthy journal. Prescription for a Healthy Journal. PLoS Med. 2004;1(1):e22. https://doi.org/10.1371/ journal.pmed.0010022.

6. International Committee of Medical Journal Editors. Advertising. Available from: http://www.icmje.org/recommendations/browse/publishing-andeditorial-issues/advertising.html (Accessed Mar 2021).

7. World Association of Medical Editors. Principles of Transparency and Best Practice in Scholarly Publishing. Available from: http://wame.org/ principles-of-transparency-and-best-practice-in-scholarly-publishing (Accessed Mar 2021).

8. Vlassov W. Is content of medical journals related to advertisements? Casecontrol study. Croat Med J. 2007:48(6):786-90. https://doi.org/10.3325/cmj.2 007.6.786.

9. Wilkes MS, Doblin BH, Shapiro MF. Pharmaceutical advertisements in leading medical journals: experts' assessments. Ann Intern Med. 1992; 116(11):912-9. https://doi.org/10.7326/0003-4819-116-11-912.

10. Villanueva P, Peiró S, Librero J, Pereiró I. Accuracy of pharmaceutical advertisements in medical journals. Lancet. 2003;361(9351):27-32. https:// doi.org/10.1016/S0140-6736(03)12118-6.

11. Lankinen KS, Levola T, Marttinen K, Puumalainen I, Helin-Salmivaara A. Industry guidelines, laws and regulations ignored: quality of drug advertising in medical journals. Pharmacoepidemiol Drug Saf. 2004;13(11): 789-95. https://doi.org/10.1002/pds.1017.

12. Santiago MG, Bucher HC, Nordmann AJ. Accuracy of drug advertisements in medical journals under new law regulating the marketing of pharmaceutical products in Switzerland. BMC Med Inform Decis Mak. 2008; 8(1):61. https://doi.org/10.1186/1472-6947-8-61.

13. Othman N, Vitry Al, Roughead EE. Quality of claims, references and the presentation of risk results in medical journal advertising: a comparative study in Australia, Malaysia and the United States. BMC Public Health. 2010;10:294

14. Dhanaraj E, Nigam A, Bagani S, Singh H, Tiwari P. Supported and unsupported claims in medicinal drug advertisements in Indian medical journals. Indian J Med Ethics. 2011;8(3):170-4. https://doi.org/10.20529/ IJME.2011.067.

15. Lexchin J. Statistics in drug advertising: what they reveal is suggestive what they hide is vital. Int J Clin Pract. 2010;64(8):1015-8. https://doi.org/10.1111/ j.1742-1241.2010.02398.x

16. Zetterqvist AV, Mulinari S. Misleading advertising for antidepressants in Sweden: a failure of pharmaceutical industry self-regulation. PLoS One. 2009;8:e62609.

17. Korenstein D, Keyhani S, Mendelson A, Ross JS. Adherence of pharmaceutical advertisements in medical journals to FDA guidelines and content for safe prescribing. PLoS One. 2011;6(8):e23336. https://doi.org/1 0.1371/journal.pone.0023336.

18. Othman N, Vitry Al, Roughead EE. Quality of pharmaceutical advertisements in medical journals: a systematic review. PLoS One. 2009;4(7):e6350. https:// doi.org/10.1371/journal.pone.0006350.

19. Spurling GK, Mansfield PR, Montgomery BD, Lexchin J, Doust J, Othman N, et al. Information from pharmaceutical companies and the quality, quantity, and cost of physicians' prescribing: a systematic review. PLOS Med. 2010; 7(10):e1000352. https://doi.org/10.1371/journal.pmed.1000352.

20. Journal of the Danish Medical Association [Ugeskrift for Læger]. Available from: http://ugeskriftet.dk.

21. von Elm E, Altman DG, Egger M, Pocock SJ, Gøtzsche PC, Vandenbroucke JP. STROBE Initiative. The Strengthening the Reporting of Observational Studies in Epidemiology (STROBE) statement: guidelines for reporting 
observational studies. PLoS Med. 2007:4:e296. https://doi.org/10.1371/journa l.pmed.0040296.

22. Lægehåndbogen [The Medical Handbook]. Available from: https://www. sundhed.dk/sundhedsfaglig/laegehaandbogen/.

23. European Commission. Notice to applicants. A guideline on summary of product characteristics (SmPC). Revision 2. September 2009. Available from: https://ec.europa.eu/health//sites/health/files/files/eudralex/vol-2/c/smpc_ guideline_rev2_en.pdf (Accessed Mar 2021).

24. Danish Medicines Agency. Available from: https://www.medicinpriser.dk/.

25. US Food and Drug Administration. Drug Safety Communications. Available from: https://www.fda.gov/drugs/drug-safety-and-availability/drug-safetycommunications.

26. European Medicines Agency. Medicines. Available from: https://www.ema. europa.eu/en/medicines.

27. US Food and Drug Administration. Postmarketing Requirements and Commitments. Available from: https:/www.accessdata.fda.gov/Scripts/cder/ pmc/index.cfm.

28. The European Union electronic Register of Post-Authorisation Studies (EU PAS Register). Available from: http://www.encepp.eu/encepp/ studySearch.htm.

29. Ducharme FM, Chroinin MN, Greenstone I, Lasserson TJ. Addition of longacting beta2-agonists to inhaled steroids versus higher dose inhaled steroids in adults and children with persistent asthma. Cochrane Database Syst Rev. 2010;4:CD005533.

30. Busse WW, Bateman ED, Caplan AL, Kelly HW, O'Byrne PM, Rabe KF, et al. Combined analysis of asthma safety trials of long-acting beta2-agonist. N Engl J Med. 2018:378(26):2497-505. https://doi.org/10.1056/NEJMoa1716868.

31. Nannini JL, Lasserson TJ, Poole P. Combined corticosteroid and long-acting

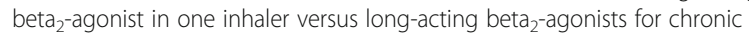
obstructive pulmonary disease. Cochrane Database Syst Rev. 2012;9: CD006829.

32. Farne $\mathrm{HA}$, Cates $\mathrm{CJ}$. Long-acting beta ${ }_{2}$-agonist in addition to tiotropium versus either tiotropium or long-acting beta $a_{2}$-agonist alone for chronic obstructive pulmonary disease. Cochrane Database Syst Rev. 2015;10: CD008989.

33. Weisler RH, Pandina GJ, Daly EJ, Cooper K, Gassmann-Mayer C. Randomized clinical study of a histamine $\mathrm{H} 3$ receptor antagonist for the treatment of adults with attention-deficit hyperactivity disorder. CNS Drugs. 2012;26(5): 421-34. https://doi.org/10.2165/11631990-000000000-00000.

34. US Food and Drug Administration. Center for Drug Evaluation and Research. NDA 22-512. Summary review. 19 Oct 2010. Available from: https://www.accessdata.fda.gov/drugsatfda_docs/nda/2010/022512Orig1 s000SumR.pdf (Accessed Mar 2021).

35. US Food and Drug Administration. Center for Drug Evaluation and Research. NDA 22-439. Medical office review. 10 Aug 2011. Available from: https://www.accessdata.fda.gov/drugsatfda_docs/nda/2011/2024390rig1 s000MedR.pdf (Accessed Mar 2021).

36. Koesters M, Ostuzzi G, Guaiana G, Breilmann J, Barbui C. Vortioxetine for depression in adults. Cochrane Database Syst Rev. 2017;7:CD011520.

37. European Medicines Agency. EMA/737723/2013. Assessment report Abilify Maintena. 19 September 2013. Available from: https://www.ema.europa.eu/ documents/assessment-report/abilify-maintena-epar-public-assessmentreport_en.pdf (Accessed March 2021).

38. Moberley S, Holden J, Tatham DP, Andrews RM. Vaccines for preventing pneumococcal infection in adults. Cochrane Database Syst Rev. 2013;1: CD000422.

39. Bonten MJ, Huijts SM, Bolkenbaas M, et al. Polysaccharide conjugate vaccine against pneumococcal pneumonia in adults. N Engl J Med. 2015;372(12): 1114-25. https://doi.org/10.1056/NEJMoa1408544.

40. IQWiG Reports - Commission No. A14-12. Canagliflozin - Benefit assessment according to §35a Social Code Book V. 12 June 2014. Available from: https://www.iqwig.de/en/projects-results/projects/drug-a ssessment/a14-12-canagliflozin-benefit-assessment-according-to-35a-socialcode-book-v-dossier-assessment.6098.html (Accessed Mar 2021).

41. FDA Drug Safety Communication: FDA warns that SGLT2 inhibitors for diabetes may result in a serious condition of too much acid in the blood. 15 May 2015. Available from: https://www.fda.gov/media/92185/download (Accessed Mar 2021).

42. FDA drug safety communication: FDA revises label of diabetes drug canagliflozin (Invokana, Invokamet) to include updates on bone fracture risk and new information on decreased bone mineral density. 10 September
2015. Available from: https://www.fda.gov/Drugs/DrugSafety/ucm461449. htm (Accessed Mar 2021).

43. FDA drug safety communication: FDA revises labels of SGLT2 inhibitors for diabetes to include warnings about too much acid in the blood and serious urinary tract infections. 4 December 2015. Available from: https://www.fda. gov/Drugs/DrugSafety/ucm475463.htm (Accessed Mar 2021).

44. FDA drug safety communications: FDA warns about new impulse-control problems associated with mental health drug aripiprazole (Abilify, Abilify Maintena, Aristada). 3 May 2016. Available from: https://www.fda.gov/Drugs/ DrugSafety/ucm498662.htm (Accessed Mar 2021).

45. FDA Drug Safety Communication: Interim clinical trial results find increased risk of leg and foot amputations, mostly affecting the toes, with the diabetes medicine canagliflozin (Invokana, Invokamet); FDA to investigate. 18 May 2016. Available from: https://www.fda.gov/media/98075/download (Accessed Mar 2021).

46. FDA Drug Safety Communication: FDA strengthens kidney warnings for diabetes medicines canagliflozin (Invokana, Invokamet) and dapagliflozin (Farxiga, Xigduo XR). 14 June 2016. Available from: https://www.fda.gov/ media/98683/download (Accessed Mar 2021).

47. European Medicines Agency. EMA completes review of inhaled corticosteroids for chronic obstructive pulmonary disease. 14 July 2016. Available from: https:/www.ema.europa.eu/en/medicines/human/referrals/ inhaled-corticosteroids-containing-medicinal-products-indicated-treatmentchronic-obstructive (Accessed Mar 2021).

48. FDA drug safety communication: FDA confirms increased risk of leg and foot amputations with the diabetes medicine canagliflozin (Invokana, Invokamet, Invokamet XR). 16 May 2017. Available from: https://www.fda. gov/Drugs/DrugSafety/ucm557507.htm (Accessed Mar 2021).

49. FDA Drug Safety Communications: FDA review finds no significant increase in risk of serious asthma outcomes with long-acting beta agonists (LABAs) used in combination with inhaled corticosteroids (ICS). 20 December 2017. Available from: https://www.fda.gov/Drugs/DrugSafety/ucm589587.htm (Accessed Mar 2021)

50. European Medicines Agency. Modified-release paracetamol-containing products to be suspended from EU market. 15 December 2017. Available from: https:/www.ema.europa.eu/en/news/modified-release-paracetamol-conta ining-products-be-suspended-eu-market (accessed Mar 2021).

51. FDA warns about rare occurrences of a serious infection of the genital area with SGLTT2 inhibitors for diabetes. 29 August 2018. Available from: https:// www.fda.gov/Drugs/DrugSafety/ucm617360.htm (Accessed Mar 2021).

52. Davis C, Naci H, Gurpinar E, Poplavska E, Pinto A, Aggarwal A. Availability of evidence of benefits on overall survival and quality of life of cancer drugs approved by European medicines agency: retrospective cohort study of drug approvals 2009-13. BMJ. 2017;359:j4530.

53. Wieseler B, McGuaran N, Kaiser T. New drugs: where did we go wrong and what can we do better? BMJ. 2019;366:14340.

54. Boesen K, Simonsen AL, Danborg PB, Jørgensen KJ, Gøtzsche PC Lægemiddelannoncer i Ugeskrift for Læger bør ikke forekomme [Medical advertisements in the Journal of the Danish Medical Association should not occur]. Ugeskr Laeger. 2018;180:1596-7.

55. Nu forsvinder lægemiddelannoncer fra Ugeskrift for Læger [Now medical advertisements disappear from the Journal of the Danish Medical Association]. 19 June 2020. Available from: https://ugeskriftet.dk/nyhed/nuforsvinder-laegemiddelannoncer-fra-ugeskrift-laeger (accessed Mar 2021).

56. Boesen $\mathrm{K}$, Simonsen AL, Jørgensen KJ. Ugeskriftet bør ikke bringe annoncer for lægemidler [The Journal of the Danish Medical Association should not publish medical advertisements]. Ugeskr Laeger. 2015;177:2446.

57. The Lancet Editors. The direct-to-consumer advertising genie. Lancet. 2007; 369:1.

58. Geyer R. The politics of EU health policy and the case of direct-to-consumer advertising for prescription drugs. Br J Politics Int Relat. 2011;13(4):586-602. https://doi.org/10.1111/j.1467-856X.2011.00460.X.

59. Schwartz LM, Woloshin S. Medical marketing in the United States, 19972016. JAMA. 2019;321(1):80-96. https://doi.org/10.1001/jama.2018.19320.

60. Shuchman M. Drug risks and free speech - can congress ban consumer drug ads? N Engl J Med. 2007;356(22):2236-9. https://doi.org/10.1056/ NEJMp078080

61. American Medical Association. AMA calls for ban on direct to consumer advertising of prescription drugs and medical devices. Available from: https://www.ama-assn.org/press-center/press-releases/ama-calls-ban-dtc-a ds-prescription-drugs-and-medical-devices (Accessed Apr 2021). 
62. Lundh A, Barbateskovic M, Hrobjartsson A, Gøtzsche PC. Conflicts of interest at medical journals: the influence of industry-supported randomised trials on journal impact factors and revenue - cohort study. PLoS Med. 2010; 7(10):e1000354. https://doi.org/10.1371/journal.pmed.1000354.

63. Glassman PA, Hunter-Heyes J, Nakamura T. Pharmaceutical advertising revenue and physician organizations: how much is too much? West J Med. 1999;171:234-9.

64. Informa PLC. Annual report and accounts 2019. Not dated. Available from: https://www.informa.com/globalassets/documents/investor-relations/2020/ informa-annual-report-2019.pdf (accessed Mar 2021).

65. RELX annual report and financial statements 2019. Not dated. Available from: https://www.relx.com/ /media/Files/R/RELX-Group/documents/ reports/annual-reports/2019-annual-report.pdf (accessed Mar 2021).

66. Egilman DS, Collins GDYCB, Falender J, Shembo N, Keegan C, Tohan S. The marketing of OxyContin ${ }^{\bullet}$ a cautionary tale. Indian J Med Ethics. 2009;4:183-93.

67. Hadland SE, Rivera-Aguirre A, Marshall BDL, Cerdá M. Association of pharmaceutical industry marketing of opioid products with mortality from opioid-related overdoses. JAMA Netw Open. 2019;2(1):e186007. https://doi. org/10.1001/jamanetworkopen.2018.6007.

68. Ho JY, Hendi AS. Recent trends in life expectancy across high income countries: retrospective observational study. BMJ. 2018;362:k2562.

69. Woolf SH, Schoomaker H. Life expectancy and mortality rates in the United States, 1959-2017. JAMA. 2019;322(20):1996-2016. https://doi.org/10.1001/ja ma.2019.16932.

70. Institute für Qualität und Wirtschaflichkeit im Gesundheitswesen. IQWiG Reports - Commission No. A15-31 Tiotropium/olodaterol -Benefit assessment according to §35a Social Code Book V1. 13 Aug 2015. Available from: https://www.iqwig.de/download/A15-31_Tiotropium-olodaterol_Extra ct-of-dossier-assessment.pdf (accessed Mar 2021).

71. Centers for Disease Control and Prevention. Understanding the epidemic. Page updated 17 March 2021. Available from: https://www.cdc.gov/ drugoverdose/epidemic/index.html (accessed Mar 2021).

72. Hernandez I, Good CB, Cutler DM, et al. The contribution of new product entry versus existing product inflation in the rising costs of drugs. Health Aff. 2019;1:76-83.

\section{Publisher's Note}

Springer Nature remains neutral with regard to jurisdictional claims in published maps and institutional affiliations.

Ready to submit your research? Choose BMC and benefit from:

- fast, convenient online submission

- thorough peer review by experienced researchers in your field

- rapid publication on acceptance

- support for research data, including large and complex data types

- gold Open Access which fosters wider collaboration and increased citations

- maximum visibility for your research: over $100 \mathrm{M}$ website views per year

At $\mathrm{BMC}$, research is always in progress.

Learn more biomedcentral.com/submissions 